\title{
Sound Characteristics and Sound Prediction of the Traditional Musical Instrument the Three-Rattle Angklung
}

\author{
Waluyo Adi Siswanto, Lina Tam and Md Zainorin Kasron \\ Department of Engineering Mechanics, Faculty of Mechanical and Manufacturing Engineering, Universiti Tun \\ Hussein Onn Malaysia (UTHM), 86400 Parit Raja, Batu Pahat, Johor Malaysia
}

\begin{abstract}
(Received 20 June 2011; Provisionally Accepted 21 March 2012, Accepted 14 May 2012)
The three-rattle angklung is a traditional musical instrument made of bamboo. The objective of this research is to observe the unique sound characteristics of the three-rattle angklung. The sound characteristics data can be used for defining digital sound of angklung to be played in a digital synthesizer. One set of angklung from the big size $C_{5}$ to the small size $C_{6}$ is recorded and analyzed in terms of the frequency contents. The sound characteristics of angklung are represented by four dominant frequency contents and the corresponding relative amplitudes of each rattle bamboo tube. This paper also introduces an equation model to predict the sound produced by the bamboo of the three-rattle angklung. This research reveals that bamboo rattles 2 and 3 produce the fundamental note, and bamboo rattle 1 generates a higher octave with the same note. Each bamboo rattle produces fundamental frequency note, its harmonics, and overtones. It is also found that three-rattle angklung can produce an accurate frequency almost in every note.
\end{abstract}

\section{INTRODUCTION}

The angklung is a traditional musical instrument that originated from western Java, Indonesia. It is made of bamboo tubes with frames. According to Widjaya, ${ }^{1}$ there are only three types of bamboo that can be used for angklung: bambu tutul or Bambusa vulgaris Schrad. ex J. C. Wendl. var. maculata Widjaja; bambu hitam or Gigantochloa atter (Hassk.) Kurz ex Munro; and bambu apus or Gigantochloa apus Bl. ex Schultes $f$. However, the most common used for musical instruments including angklung is bambu hitam.

There are several types of angklung found in certain areas of Indonesia. They are Angklung Baduy, Angklung Dogdog Lojor, Angklung Gubrag, and Angklung Badeng. All of them were originally used for ritual activities related to traditional rice harvests. When modern harvesting was introduced, people then used them for entertaining purposes as percussion musical instruments and even played in musical orchestras with modern instruments. ${ }^{2}$ The size of angklung varies from a small palm size up to $60 \mathrm{~cm}$ tall corresponding to the frequency produced when it is shaken. In general, a small angklung generates a higher frequency. The bigger the size of the angklung, the lower the frequency it produces.

In Malaysia, angklung are used together with hobby-horse dancing and mostly found in the state of Johor, as documented by Matusky, ${ }^{3}$ Ang, ${ }^{4}$ and also in a government official publication written by Nasuruddin. ${ }^{5}$ Some Malaysian schools also have angklung orchestras in which each child plays an angklung of a different size, in a manner similar to a handbell choir. ${ }^{6}$ There are two types of angklung in regard to the number of tubes: two tubes (two-rattle) and three tubes (three-rattle). In Johor, Malaysia, the three-rattle angklung is the most popular used by the community. ${ }^{7}$ A photograph of a three-tube (threerattle) angklung found in Johor is shown in Fig. 1.

In general, the angklung has two main parts: the frame and

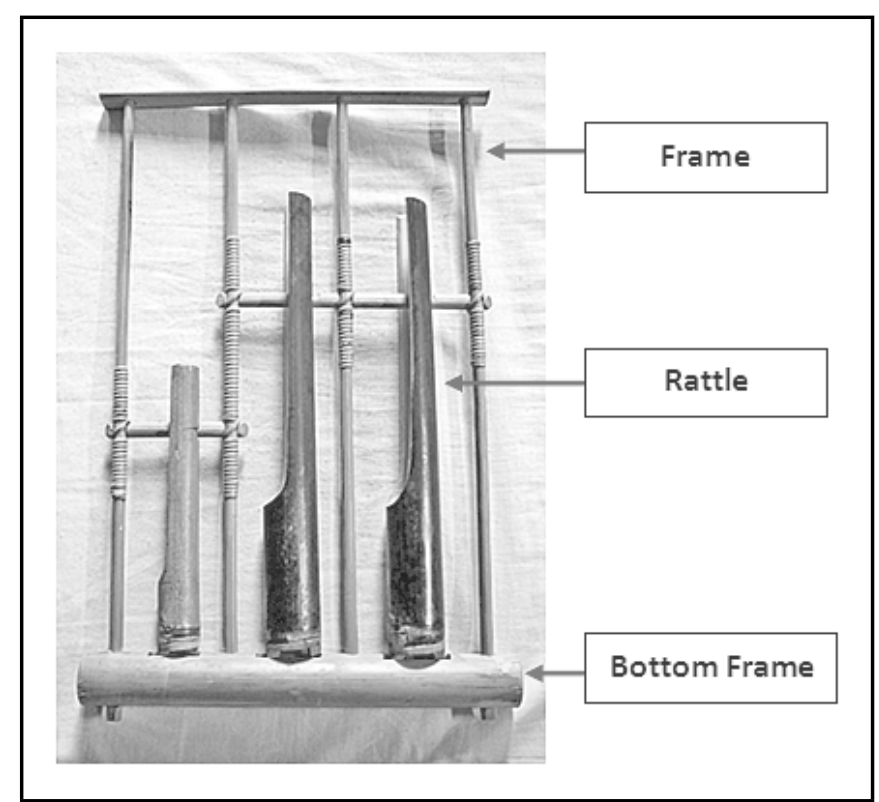

Figure 1. A three-rattle angklung.

the rattle tubes. In three-rattle angklung, the first rattle is the shortest tube, and the other two rattle tubes are almost identical. The main function of the frame is to hold the rattle tubes. The angklung is played by holding the upper frame and shaking the bottom frame sideways. When the tines hit the slits at the bottom frame, the air wave will transmit through the air resonator of the hollow bamboos to create sound. Each rattle of the angklung will produce a different pitch frequency depending on the length of the tube, the tongue, and the diameter of the tube. One set of angklung from note $C_{5}$ to note $C_{6}$ is shown in Fig. 2.

The sound produced by a musical instrument has a typical characteristic identified by four parameters: pitch, duration, quality, and intensity. Apart from the rattling sound mecha- 